\section{Developing an academia-based public health observatory: the new global public health observatory with emphasis on urban health at Johns Hopkins Bloomberg School of Public Health}

\author{
O desenvolvimento de um observatório de saúde \\ com base na academia: o novo observatório de \\ saúde pública com ênfase na saúde urbana na \\ Johns Hopkins Bloomberg School of Public Health
}

\author{
El desarrollo de un observatorio de salud basado \\ en la academia: el nuevo observatorio de salud \\ pública con énfasis en la salud urbana en la Johns \\ Hopkins Bloomberg School of Public Health
}

\begin{abstract}
Health observatories may differ according to their mission, institutional setting, topical emphasis or geographic coverage. This paper discusses the development of a new urban-focused health observatory, and its operational research and training infrastructure under the academic umbrella of the Department of Epidemiology and the Institute of Urban Health at the Johns Hopkins Bloomberg School of Public Health (BSPH) in Baltimore, USA. Recognizing the higher education mission of the BSPH, the development of a new professional training in public health was an important first step for the development of this observatory. This new academia-based observatory is an innovative public health research and training platform offering faculty, investigators, professional epidemiology students and research partners a physical and methodological infrastructure for their operational research and training activities with both a local urban focus and a global reach. The concept of a public health observatory and its role in addressing social health inequalities in local urban settings is discussed.
\end{abstract}

Equity in Health; Global Health; Urban Health
Carlos Castillo-Salgado 1

\section{Resumo}

Os observatórios de saúde podem se diferenciar de acordo com sua missão, contexto institucional, enfoque temático e cobertura geográfica. $O$ artigo discute o desenvolvimento de um novo observatório de saúde pública com enfoque urbano e sua pesquisa operacional e infraestrutura de ensino, sob a égide acadêmica do Departamento de Epidemiologia e do Instituto de Saúde Urbana da Johns Hopkins Bloomberg School of Public Health (BSPH) em Baltimore, Estados Unidos. A Bloomberg School reafirmou sua missão no ensino superior ao lançar uma nova formação profissional em saúde pública como primeiro passo importante no desenvolvimento do observatório. O novo observatório com base na academia é uma plataforma inovadora para o ensino e pesquisa em saúde pública que oferece ao corpo docente, pesquisadores, alunos de epidemiologia, e parceiros em projetos de pesquisa uma infraestrutura física e metodológica para suas atividades de pesquisa operacional e capacitação, com enfoque urbano local e alcance global. Discute-se o conceito de um observatório de saúde pública e seu papel no enfrentamento das desigualdades sociais em saúde em contextos urbanos locais.

Equidade em Saúde; Saúde Global; Saúde Urbana 


\section{Introduction}

During the last decade, the World Health Organization Center for Health Development in Kobe, Japan (known as the WHO Kobe Centre) has promoted research globally to improve urban health metrics, and to develop tools for improving urban health and equity using a 'social determinants of health' framework. In recent years, the WHO Kobe Centre has been investigating health observatories as a possible institutional mechanism for improving public health intelligence and its application in urban areas 1,2,3.

The seminal work of the public health observatories of England 4, the national network of regional health observatories in France 5, and multiple health observatories located in Canada 6,7,8, Europe 9, Latin America 10 and Africa 11,12 in different institutional settings offer insight into an innovative way to use available health and population-based data from different sources and transform it into public health intelligence for practical applications.

This paper discusses the context and processes involved in developing a new urban-focused health observatory and its operational research and training infrastructure under the academic umbrella of the Department of Epidemiology and the Institute of Urban Health of the Johns Hopkins Bloomberg School of Public Health (BSPH) in Baltimore, USA.

\section{Concept of Public Health Observatory}

A public health observatory 13 , especially at the national or local level, can be operationalized as a policy-oriented virtual center aimed at performing systematic, ongoing, and integrated observations of population health and health systems in order to support effective evidencebased health policy, planning, decision-making and action. Based on its capacity and functions, an observatory can serve simultaneously as a functional center, encompassing public health surveillance, health systems monitoring, specialized analysis of health-policy issues, healthrelated early warning, publication of policy-oriented advisories and health information, as well as knowledge production and management 14 . The ultimate aim is to contribute to improvement of health and quality of life of the population, with an emphasis on the reduction of social health inequalities.

A major obstacle in the public health agenda at local and global levels is the current "knowdo" gap between what we know and what we do, between research and practice in public health.
A public health observatory can be a platform for building better links between the already available public health information and knowledge and the application to public health policies and action. It can also serve a pivotal role in offering professional training programs in equity-oriented operational research and health situation analyses.

\section{Paradigm for public health operational research}

The accelerated trends of social and health inequalities in urban settings threaten to disrupt the social, economic and political stability of societies in both developed and developing economies.

Considering the challenging times for global public health, particularly dealing with the unmet health needs of growing disadvantaged populations in urban settings, and an emergence of socially determined health inequalities in both developed and developing countries, a public health framework which emphasizes the social dimensions of health is required. The social determinants of health framework 15 provided the theoretical bases for a new paradigm for equityfocused public health operational research. In spite of significant evidence recognizing that the poorest groups in society share the highest burden of disease, very few academic institutions around the world have offered new professional training to deal with this critical social challenge.

Many orthodox research methods used in conventional research and training institutions, both public and private, focus on a few specific determinants of health often operating at the individual level. This approach, however, is insufficient to dynamically assess, monitor and evaluate the impact of the broader determinants of health and social interventions in reducing and eliminating the growing social health inequalities at the local community level. Strategies to promote health equity, or to reduce or eliminate health inequalities, whether at local or global levels, require the methodological lenses and tools offered by the social determinants of health framework. Health observatories can and should be well positioned to address the broader determinants of health and contribute to the improvement of health equity. 


\section{Developing an academia-based Public Health Observatory}

There are different types of public health observatories depending on their mission, institutional setting, topical emphasis, or geographic coverage. New guidance for local public health observatories recently published by the WHO Kobe Centre describes these varying important aspects 16 .

This paper presents the case of an academia-based health observatory. Examples of academia-based health observatories in Latin America are found in Belo Horizonte, Brazil 17 (focus on urban health), Cali, Colombia 18 (focus on citizen security) and Ciudad Juarez, Mexico 19 (focus on violence). In 2003, the State University of New York at Buffalo developed a Population Health Observatory 20 , which is the only academia-based health observatory in the USA. The lack of public health funding in the USA may explain in part why there is a limited number of public health observatories, especially based in academic public health institutions. Most of the funding from the US National Institutes of Health, the lead funding agency for health research in the country, is dedicated to medical and etiologic research.

In 2013, the BSPH, under the leadership of the Department of Epidemiology and the Urban Health Institute, established its Global Public Health Observatory with an emphasis on Urban Health and the City of Baltimore, its local community, but also with a wide global reach. The Department of Epidemiology, jointly with the Urban Health Institute, recognized the need for developing the first public health observatory of its kind in a major academic public health institution in the USA to actively expedite the translation of epidemiological evidence into innovative public health programs and interventions. Dr. Bobby Jacobson, Director of the London Health Observatory from 2001-2013, officially launched the observatory on November 2013 with an inaugural lecture about the ten years' experience of the London Health Observatory.

The internal governance of the observatory includes the leadership of the Department of Epidemiology, the Urban Health Institute, the Center for Prevention of Youth Violence and the Center for Adolescent Health. Additional stakeholders in the governance of the observatory are representatives of local community groups, and institutional associates such as the Baltimore City Health Department and the Consortium for Public Health Managers in Epidemiology in Latin America and Spain. In 2014, the leadership of the "Health Situation Room" of the Brooklyn Hospi- tal Center in Brooklyn, NewYork was added in the governance of the observatory. The framework and governance model proposed by Caiaffa et al. 3 were very influential in the development of the observatory.

The BSPH Observatory is a public health research and training platform offering faculty, investigators, professional epidemiology students and research partners a physical and methodological infrastructure for their operational research and training activities. These activities are linked with other academic departments and research centers of the BSPH and with local public health agencies. The mission of the BSPH observatory is to promote and sustain research on local and global urban health combined with advanced training in professional epidemiology methods and public health intelligence. As part of its professional practice it is also a consultative platform for the examination of relevant comparative effectiveness research on critical urban health problems. In addition, the observatory promotes research and the exchange of key public health evidence for translation into local and national urban and public health policies and programs.

The BSPH observatory includes among its analytical methods, multi-level analyses to estimate the effects of the urban context (neighborhood-level effects) on health inequalities after controlling for individual variables. This research approach provides strategic importance to observatories that examine how structural and social processes affect the health and well-being of urban communities.

The observatory was conceived as a "thinktank", an operational organization performing complex health situation analyses in a shorter timespan than conventional research centers and producing local urban epidemiological profiles and health priority assessments with greater impartiality than government agencies with a political agenda or community groups with specific interests. In addition, the observatory plays a supporting role in evaluating progress made by local health departments in improving public health and reducing health inequality.

\section{Incorporating core competencies into training and applied research of the Public Health Observatory}

One important consideration for the development of the observatory was the real need felt by the academic authorities of professional epidemiology and public health practice to have the same rigor in analytical methods used in etio- 
logic research, or basic science, also applied to professional public health training and practice.

During 2005-2009 the BSPH's Department of Epidemiology reviewed its internal graduate training programs recognizing a changing public health landscape. This new landscape was being shaped by the health impact of economic globalization, the growing importance of the social determinants of health 15 , the revised International Health Regulations 21, new paradigms for public health surveillance 22 , various global health initiatives, and the increased attention to health equity reflected in the Healthy People 2020 Goals in the USA 23. The Johns Hopkins University also recognized the importance of urban health issues dominating the public health agenda in most of the countries of the world. To address the growing urban public health challenges the university included in its new 2013-2017 fundraising campaign the area of interdisciplinary research on urban and health issues.

The review process included meetings with faculty members, graduate students, graduates from previous years, professional epidemiologists from national and international public health agencies, and leaders of civil society working on Baltimore City's health and health equity issues. The review resulted in the creation of a new Professional-Applied Epidemiology Methods Track Program. This new track program provided the initial building blocks of the observatory. The program is a school-wide effort to strengthen local and global capacity in performing health situation analysis and problem solving to support effective equity-focused resource allocation and program implementation with an emphasis on local urban health issues. This training approach incorporates a series of problem-solving modules with explicit recognition of the key concepts, methods and tools needed to deal with specific real public health problems. The program is designed to train future leaders in advanced epidemiological methods needed in modern public health practice. The track covers methods for health priority assessments; health needs assessments, epidemiological stratification of public health problems, measuring health inequalities, and evaluation of effectiveness of public health programs using real public health scenarios and available health information datasets. Selected methods for translating epidemiologic data for decision-making are also covered. Additionally, this program addresses the role of available epidemiologic evidence and translational research for public health programs. Several of the scholars and post-doctoral fellows working on their projects in the observatory benefit from this professional training. The observa- tory also offers doctoral students research opportunities to complete their required "professional doctoral practicum".

Of analytical importance is the role of the "public health as problem-solving activity" approach 24 in the vision of the observatory work. This methodological consideration was added so that the observatory focuses on identifying relevant health situations, critical problems, and processes that require solutions, rather than only addressing scholarly research questions and biomedical investigations. Since many of the existing advanced training programs in the health sciences are tailored to etiologic and biomedical research, it was considered important to develop the observatory as an academic institutional process that integrated applied and translational research within the teaching cycle. Special consideration is given to urban health research, as cities are main sites of public health concern and where better interventions are needed to understand how social, political and economic determinants profile the health conditions of urban populations.

\section{Linking the observatory with local and global institutional partners}

The observatory's role is to connect the analytical skills fostered in the academic training program with distinctive public health projects commissioned by the local urban health department and other institutional partners. The BSPH observatory is designed to facilitate relevant academic research agendas to better reflect the public health concerns of urban populations, in particular, the local populations in the City of Baltimore. Examples of these collaborative efforts, including those initiated before the official launch of the observatory, are the 2012 Update of the Neighborhood Health Profiles of Baltimore City 25, the 2012-2014 health impact assessment projects contracted by the Baltimore City Health Department 26, and the Health Situation Room project 27 and the Epidemiological Profiles of Brooklyn's Neighborhoods developed in partnership with the Brooklyn Hospital Center in New York.

"Health in All Policies" 28 is recognized as a framework for the current projects of the Equity-Focused Health Impact Assessments for the Baltimore City Health Department. From 20132015, five projects have been developed involving community leaders, academic researchers and interagency policy makers.

As indicated above, one priority research agenda has been to support the assessments of unmet health needs of different urban popu- 
lations, as place is relevant for health inequality variations. Two important projects included measuring the unmet health needs of the neighborhoods of Baltimore City in conjunction with the Baltimore City Health Department and the unmet health needs of the neighborhoods of Brooklyn, New York in conjunction with the Brooklyn Hospital Center. These projects aimed to recognize the specific way the distal and proximal social determinants of health shape the differences between local urban neighborhoods. The vision of population health distributions and their space are being recognized for reexamining the potential new directions of more equityfocused public health interventions to address the critical needs of inner-city and marginal residents of urban areas.

The observatory is currently collaborating with various local civil society groups to address health equity issues in Baltimore City. A key partner is Equity Matters (EM) 29, a major public health NGO working in Baltimore City, and a member of Place Matters, a national organization working with local communities on health equity and social determinants of health in the USA. Equity Matters is also the Baltimore City partner of the National Collaborative for Health Equity in the USA. The observatory provided training in health equity methods to the EM's leaders and participated in the methodological review of its Report of Health Inequities in Baltimore, Maryland, 2014. The observatory regularly provides methodological advice to its urban health initiatives, including geospatial analyses of health disparities by neighborhoods in Baltimore City.

At the global level, the Observatory has professional alliances with the World Health Organization, the Pan American Health Organization, the Academic Consortium of Public Health Institutions in Brazil, Colombia, Chile, Mexico, Argentina and Spain. In addition, the observatory is coordinating professional activities with the Latin American Global Health Association (ALASAG). In a globalized public health network, urban health problems 30 and risks in one part of the world, including disease outbreaks, can spread at an unprecedented fast rate to other parts of the world. Global problems 31 and urban local solutions need to be linked. A social epidemiological understanding of global health problems such as obesity 32,33 and crime might benefit from systematic assessment of correlations of income inequalities with other markers of local urban health ${ }^{34}$.

\section{Strengths of the Public Health Observatory at the BSPH in Baltimore}

There are several important advantages of having the observatory under the academic umbrella of the BSPH. The BSPH offers advanced interdisciplinary methodological expertise in most research areas of public health, including multilevel analysis methods for urban health 35 . It is well known in the fields of epidemiology and biostatistics for its expertise in handling largescale data sets and developing new methods to handle complex longitudinal data. By partnering with different BSPH research centers, the observatory is developing the infrastructure to work with core health data that is routinely collected in order to identify and develop data-driven and evidence-based solutions for priority local public health needs. An added value is the US Center of the Cochrane Collaboration that is hosted in the BSPH Department of Epidemiology, which provides high-level expertise in systematic reviews and meta-analyses.

An important research expansion of the observatory has been the incorporation of analysis of geospatial distributions of health clusters in urban areas revealing the concentration of social health inequalities in specific locations. Studying the local spatial patterns of urban health problems linked to poverty 36 gives a cross-sectional view of the great differences in poor living conditions and quality of life disproportionately affecting several inner city populations 37 . These assessments provide evidence of the enormous challenges that municipalities and civil society groups face in managing urbanization without equitable distribution of social assets. Community urban asset mapping is one important analytical line of research of the observatory developed to support policy makers and foundations in the location of facilities and resources in critical urban communities.

With its expertise in global health, the observatory is also able to offer technical assistance for the improvement of health information systems and core health indicators, the development of new public health metrics, and adaptation and improvement of existing methods and technologies for use in public health practice by local health departments and other organizations. It can facilitate the process of applying or adapting global standards and tools to the local context, for example, by performing an assessment of health information systems using a framework and tool developed by the WHO, and harmonizing local health information systems with global standards and guidelines including the International Classification of Diseases (ICD-10), Inter- 
national Classification of Functioning, Disability and Health (ICF) and the 2005 International Health Regulations.

In this way the observatory brings together an ideal mix of expertise for addressing priority questions facing the health situation of communities and neighborhoods, particularly in urban settings. The research infrastructure at BSPH allows for the development of new advanced methodology and greater capacity for innovation. The university also provides the observatory with institutional oversight and holds it at a high ethical standard. This environment contributes to the observatory's ability to bring together different stakeholders, both public and private. An additional advantage is the greater stability of the personnel when compared with the staff of the public health sector.

The observatory is facilitating the development of partnerships with community-based organizations in Baltimore to bridge the disconnect between the community and academic health institutions.

\section{Challenges going forward}

The main challenges are related to sustaining the financial support of partners and other stakeholders. Current funding for the activities of the observatory is generated from different sources, including grants or contracts from the Ministry of Health of Brazil, the WHO, the Pan American Health Organization, the Baltimore City Health Department, the Brooklyn Hospital Center and general funds from the BSPH. Several additional grants have been summited for the development of local public health observatories in different Latin American cities and countries and in different regions of the world.

Due to the ongoing reduction of public funding for public health research from the US government, academic-based research centers are vulnerable. Sustaining the activities of the observatory will require increasing its capacity to mobilize additional support from other funding sources, as the think-tank approach of the observatory demands a stable academic team with excellent working relations with a wide range of stakeholders.

The recent guidelines 16 for the development of new local urban health observatories generated by WHO Kobe Centre with the input of the leaders of the most important health observatories in the world is available to support the development of new local urban health observatories.

The BSPH Observatory represents a valuable mechanism to effectively identify and tackle collective health challenges of urban areas and populations. This academic observatory will play a significant advisory role in supporting the establishment of new local urban health observatories around the globe. 


\section{Resumen}

Los observatorios de salud pueden diferir de acuerdo con su misión, el contexto institucional, el enfoque temático y la cobertura geográfica. El artículo discute el desarrollo de un nuevo observatorio de salud pública con énfasis en la salud urbana y su investigación operativa y la infraestructura de la enseñanza, bajo los auspicios académicos del Departamento de Epidemiología y el Instituto de Salud Urbana de la Johns Hopkins Bloomberg School of Public Health en Baltimore, Estados Unidos. La Bloomberg School reafirmó su misión en la educación superior mediante el lanzamiento de una nueva formación profesional en la salud pública como el primer paso en el desarrollo del observatorio.
El nuevo observatorio, basado en la academia, es una plataforma innovadora para la enseñanza y la investigación en salud pública que ofrece a los profesores, investigadores, estudiantes de epidemiología y socios en proyectos de investigación, una infraestructura física y metodológica para las actividades de investigación operativa y de formación, con enfoque urbano local y alcance global. Se discute el concepto de un observatorio de salud pública y su papel en el afrontamiento a las desigualdades sociales en salud en los entornos urbanos locales.

Equidad en Salud; Salud Global; Salud Urbana

\section{References}

1. Kobe Centre for Health Development, World Health Organization. Urban health observatories: a possible solution to filling a gap in public health intelligence. Policy brief. http://www.who.int/ko be_centre/publications/uho_policybrief.pdf.

2. WHO Centre for Health Development. Urban Health Equity Assessment and Response Tool (Urban HEART). http://www.who.int/kobe_centre/ publications/urban_heart/en/index.html.

3. Caiaffa WT, Friche AA, Dias MA, Meireles AL, Ignacio CF, Prasad A, et al. Developing a conceptual framework of urban health observatories toward integrating research and evidence into urban policy for health and health equity. J Urban Health 2014; 91:1-16.

4. Association of Public Health Observatories. The former Association of Public Health Observatories of the UK and Ireland. http://www.apho.org.uk/.
5. Fédération Nationale des Observatoires Régionaux de Santé. The Federation of French Observatories. http://www.fnors.org/index.html

6. Public Health Observatory. Saskatoon Health Region, Canada. https://www.saskatoonhealthre gion.ca/Pages/Search-Results.aspx?k=health+obs ervatory\&sc=Entire+Site.

7. Ontario Public Health Standards. http://www. health.gov.on.ca/en/pro/programs/publichealth/ oph_standards/docs/ophs_2008.pdf.

8. British Columbia Framework for Public Health. http://www.health.gov.bc.ca/library/publica tions/year/2013/BC-guiding-framework-for-public-health.pdf. 
9. World Health Organization. Human resources for health observatories. Evidence-informed human resources for health policies. http://www.who.int/ hrh/resources/observatories_meeting_report.pdf.

10. Observatorio de Saude Urbana de Belo Horizonte http://medicina.ufmg.br/osubh/.

11. Kebede D, Zielinski C. The potential role of regional and national health observatories in narrowing the knowledge gap in sub-Saharan Africa. J R Soc Med 2014; 107(1 Suppl):3-5.

12. United Nations Human Settlements Programme. A guide to setting up an urban observatory. Nairobi: United Nations Human Settlements Programme; 2006.

13. Hemmings J, Wilkinson J. What is a public health observatory? J Epidemiol Community Health 2003; 57:324-6.

14. Carr-Hill R, Chalmers-Dixon P. The Public Health Observatory handbook of health inequalities measurement. http://www.sepho.org.uk/extras/rch_ handbook.aspx.

15. WHO Commission on Social Determinants of Health. Final report. http://www.who.int/social_ determinants/thecommission/finalreport/en/.

16. WHO Kobe Centre. Providing health intelligence to meet local needs: a practical guide to serving local and urban communities through public health observatories. Kobe: World Health Organization; 2014.

17. Observatorio de Saude Urbana de Belo Horizonte. http://www.medicina.ufmg.br/osubh/?page id $=1905$.

18. CISALVA-Univalle. Observatorio de Violencia Intrafamiliar de Cali. http://www.cisalva.univalle. edu.co/publicaciones/boletines/BOL1.pdf.

19. Observatorio de Seguridad y Convivencia Ciudadanas del Municipio de Juárez. http://www.obser vatoriodejuarez.org/dnn/.

20. The Population Health Observatory at the University at Buffalo. http://www.pho.sphhp.buffalo.edu.

21. World Health Organization. International health regulations (2005). http://www.who.int/ihr/publi cations/9789241596664/en/.

22. Castillo-Salgado C. Trends and directions of global public health surveillance. Epidemiol Rev 2010; 32:93-109.

23. US Department of Health and Human Services. Healthy people 2020. http://www.healthypeople. gov/2020/default.aspx.
24. National Research Council. The future of public health. http://www.nap.edu/openbook.php?re cord_id=1091\&page $=107$.

25. 2012's Baltimore City's Neighborhood's Health Profiles. http://health.baltimorecity.gov/neighborhoods/neighborhood-health-profile-reports.

26. Baltimore City Health Department. Health impact assessment website. http://www.baltimorehia.org.

27. The Brooklyn Hospital Center. The health situation room. http://www.tbh.org/health_situation_ room-hsr.

28. World Health Organization. Health in all policies: framework for country action. http:// www.who.int/healthpromotion/frameworkfor countryaction.

29. Equity Matters. Promoting equity-in-all policies. http://www.equity-matters.com/who-we-are/.

30. Galea S, Vlahov D. Urban health: evidence, challenges, and directions. Annu Rev Public Health 2005; 26:341-65.

31. Moore M, Gould P, Keary BS. Global urbanization and impact on health. Int J Hyg Environ Health 2003; 206:269-78.

32. Liu GC, Wilson JS, Qi R, Ying J. Green neighborhoods, food retail and childhood overweight: differences by population density. Am J Health Promot 2007; 21(4 Suppl):317-25.

33. Powell LM, Auld MC, Chaloupka FJ, O'Malley PM, Johnston LD. Associations between access to food stores and adolescent body mass index. Am J Prev Med 2007; 33(4 Suppl):S301-7.

34. Diez Roux AV, Mair C. Neighborhoods and health. Ann NY Acad Sci 2010; 1186:125-45.

35. Subramanian SV. Multilevel methods for public health research. In: Kawachi I, Berkman L, editors. Neighborhoods and Health. New York: Oxford University Press; 2003. p. 65-111.

36. Borrell C, Pons-Vigués M, Morrison J, Díez E. Factors and processes influencing health inequalities in urban areas. J Epidemiol Community Health 2013; 67:389-91.

37. Tyus N, Gibbons C, Robinson K, Twose C, Guyer B. In the shadow of academic medical centers: a systematic review of urban health research in Baltimore City. J Community Health 2010; 35:433-52.

Submitted on $01 /$ Sep/2014

Final version resubmitted on 22/Mar/2015

Approved on 25/Mar/2015 